\title{
EFFECTS OF ELASTIC WRAP ON MUSCLE ACTIVITY AND ISOMETRIC FORCE OF KNEE EXTENSORS
}

\author{
EFEITOS DA BANDA ELÁSTICA NA ATIVIDADEMUSCULARENA FORÇA ISOMÉTRICA DOS \\ EXTENSORES DE JOELHO
}

Original Article

ARTIGO ORIGINAL

Artículo Original

\author{
EFECTOS DE VENDA ELÁSTICA EN ACTIVIDAD MUSCULAR Y FUERZA ISOMÉTRICA DE \\ EXTENSORES DERODILLAS
}

\author{
Fábio Sisconeto de Freitas \\ (Physiotherapist) \\ Willy Andrade Gomes ${ }^{1,2}$ \\ (Physical Education Professional) \\ Paulo Henrique Marchetti ${ }^{3}$ \\ (Physical Education Professional) \\ 1. Universidade Nove de Julho, \\ São Paulo, São Paulo, Brazil. \\ 2. Universidade Metodista de \\ Piracicaba, Departamento de \\ Ciências do Movimento Humano, \\ Piracicaba, São Paulo, Brazil. \\ 3. Department of Kinesiology, \\ California State University, \\ Northridge, California, USA.
}

\section{Correspondence:}

Paulo H. Marchetti. California State University Northridge. Department of Kinesiology, 18111 Nordhoff Street, Northridge, CA. USA. dr.pmarchetti@gmail.com

\begin{abstract}
Introduction: The elastic knee wrap (EKW) is a device used by powerlifters, weightlifters and subjects undergoing strength training with the aim of stabilizing the knee joint and increasing the development of strength (carryover effect). Objective: To compare the effects of elastic knee wrap use on muscular activity of the vastus lateralis $(\mathrm{VL})$ and on knee extension force during maximum voluntary isometric contraction (MVIC) on the knee extensor chair. Methods: The study included 18 healthy male strength trained $(>1$ year) subjects (age: $25.56 \pm 4.84$ years, total body mass: $81.83 \pm 8.73 \mathrm{~kg}$, height: $176 \mathrm{~cm} \pm 5.17$ ). Three five-second maximum voluntary isometric contractions (MVICS) of the knee extensors were performed with a 10-second interval between attempts, for each experimental condition: control (C), with elastic knee wrap (EKW), and with tensor ( $T$ ). The performance of the knee extensors and VL muscle activity were evaluated. A repeated measures ANOVA was used to compare the dependent variables (carryover, peak force, IEMG and Impulse). Results: For carryover, the use of EKW presented a higher value (74.21\%) than the control condition $(p<0.001, d=0.96)$ and was $79.37 \%$ higher than the tensor $(p<0.001, d=0.97)$. Peak force was $12.2 \%$ higher in condition C compared to EKW $(p=.018, d=0.71)$. For impulse, the control condition presented an increase of $8 \%$ compared to EKW use $(p=.015, d=0.62)$. No significant differences were observed for IEMG. Conclusion: Elastic knee wrap use increased strength production capacity during knee extension. The removal of the mechanical effect originating from carryover during $\mathrm{MVIC}$ reduces the strength performance of the knee extensors, but not the muscular activation of the VL. Level of Evidence I; Therapeutic studies - Investigation of treatment results.
\end{abstract}

Keywords: Biomechanical Phenomena; Athletic Performance; Muscle Strength.

\section{RESUMO}

Introdução: A banda elástica de joelhos (BEJ) é um equipamento utilizado por powerlifters, weightlifters e sujeitos treinados em força, com o objetivo de estabilizar a articulação do joelho e aumentar o desempenho da força (efeito carry over). Objetivo: Comparar os efeitos do uso da banda elástica de joelhos na atividade muscular de vasto lateral (VL) e na força de extensores de joelhos, durante a contração voluntária máxima isométrica (CVMI) na cadeira extensora. Métodos: Participaram do estudo 18 sujeitos saudáveis (idade: 25,56 $\pm 4,84$ anos, massa corporal total: $81,83 \pm 8,73 \mathrm{~kg}$, estatura: $176 \pm 5,17 \mathrm{~cm}$ ), do gênero masculino, treinados em força (> 1 ano). Foram realizadas três contrações voluntárias máximas (CVMI's de extensores de joelho, de cinco segundos por 10 segundos de intervalo entre as tentativas, para cada condição experimental: controle (C); com banda elástica de joelhos (BEJ); e com tensor (T). Foram avaliados o desempenho de extensores de joelho e a atividade muscular de VL. Uma ANOVA com medidas repetidas foi utilizada para comparar as variáveis dependentes (carry over; pico de força, IEMG e Impulso). Resultados: Para o carry over, o uso da BEJ apresentou maior valor (74,21\%) quando comparada a condição controle $(P<0,001, d=0,96)$ e 79,37\% maior do que o tensor $(P<0,001, d=0,97)$. O pico de força foi 12,2\% maior na condição C comparado à $B E J(P=0,018, d=0,71)$. Para o impulso, a condição controle apresentou um aumento de $8 \%$ comparado ao uso da $B E J(P=0,015, d=0,62)$. Para a IEMG não foram observadas diferenças significantes. Conclusão: $O$ uso da banda elástica de joelhos aumentou a capacidade de produção de força durante a extensão de joel ho. A remoção do efeito mecânico proveniente do carry over, durante a CVMI, reduz o desempenho de força dos extensores de joelho, mas não a ativação muscular do VL. Nível de Evidência l; Estudos terapêuticos - Investigação dos resultados do tratamento.

Descritores: Fenômenos Biomecânicos; Desempenho Atlético; Força Muscular.

\section{RESUMEN}

Introducción: La venda elástica de rodillas (EKW) es un dispositivo utilizado por powerlifters, weightlifters y sujetos a entrenados en fuerza con el objetivo de estabilizar la articulación de rodilla y para aumentar el desarrollo de la fuerza (efecto carry over). Objetivo: Comparar los efectos del uso de venda elástica de rodillas en actividad muscular del vasto 
lateral (VL) y la fuerza de los extensores de rodilla durante la contracción máxima isométrica voluntaria (MVIC) en la silla extensora. Métodos: El estudio incluyó a 18 sujetos saludables (edad: $25,56 \pm 4,84$ años, masa corporal total: 81,83 $\pm 8,73 \mathrm{~kg}$, altura: $176 \mathrm{~cm} \pm 5,17$ ), sexo masculino, entrenado en fuerza ( $>1$ año). Fueron realizadas tres contracciones máximas voluntarias extensoras de rodilla (MVIC), de cinco segundos por 10 segundos de intervalo entre intentos para cada condición experimental: control (C), con las vendas eláticas de rodillas (EKW), y con tensor (T). Fueron evaluados el desempeño de los extensores de rodilla y la actividad muscular de VL. Una ANOVA con medidas repetidas fue utilizada para comparar las variables dependientes (carry over, el tope de fuerza, IEMG e Impulso). Resultados: Para el carry over, el uso de EKW presentó un valor de mayor $(74,21 \%)$ en comparación con la condición de control $(P<0,001$, $d=0,96)$ y 79,37\% mayor que el tensor $(P<0,001, d=0,97)$. El tope de fuerza con fue 12\% mayor en la condición $C$, comparado EKW $(P=.018, d=0,71)$. Para el impulso, la condición control presentó un aumento del $8 \%$ comparado al uso de la EKW ( $P=.015, d=0,62)$. Para IEMG no fueron observadas diferencias significativas. Conclusión: El uso de vendas elásticas de rodillas aumentó la capacidad de producción de fuerza durante la extensión de rodilla. La remoción del efecto mecánico proveniente del carry over durante la MVIC reduce el desempeño de fuerza de los extensores de rodilla, pero no la activación muscular del VL. Nivel de Evidencia l; Estudios terapéuticos - Investigación de los resultados del tratamiento.

Descriptores: Fenómenos Biomecánicos; Desempeno Atlético; Fuerza muscular.

\section{INTRODUCTION}

The elastic knee wrap (EKW) is a device commonly used by powerlifters, weightlifters and force-trained subjects with the goal of stabilizing the knee joint, boosting strength performance (carry over effect), and supposedly increase safety during and performing the squat exercise. ${ }^{1,2}$ The EKW has a composite manufactured of polyester frames reinforced with elastic material and measuring two meters in length, usually wrapped around the knee as tightly as possible just before the squat be executed., 4 The EKW, in general, works as an ergogenic agent that through elastic deformation of the material accumulates elastic energy and gravitational potential (during the descending phase of the squat) and consequently increases its loading capacity in the ascending phase, additional force effect known as carry over. ${ }^{1}$ Although EKW was extensively used in strength training, only three studies investigated the EKW's carry over effect on strength production, with a dynamic squatting study in powerlifters $(19,8 \%){ }_{1}^{5}$ a study with strength-trained subjects during passive squatting $(25,1 \%)^{3}$ and a study in subjects trained in strength during maximum isometric squatting (21-22\%). ${ }^{6}$ Additionally, Lake et al., ${ }^{4}$ compared the effect of EKW use on kinetic and kinematic variables during squatting in subjects trained in strength. In this study was study the soil reaction force, the mechanical force production applied to the center of mass, the vertical impulse, the horizontal displacement of the bar, the mechanical work and the power peak. The results showed that the elastic properties of EKW reduced the horizontal displacement of the bar in the downward phase by 39\%, as well as a 13.2\% increase in peak power with EKW. The authors suggested that such changes in the technique could promote changes in the pattern of muscle activation during squats with EKW (a variable that wasn't evaluated in the study). Additionally, Gomes et al., ${ }^{7}$ compared the vastus lateralis (VL) and gluteus maximus (GM) muscle recruitment patterns during dynamic squatting with and without EKW in subjects trained in strength at different intensities (60 and $90 \%$ of $1 \mathrm{RM}$ ). The results showed that the use of EKW during the squatting (90\% of 1 RM) presented a reduction of $19.7 \%$ in the muscular activation of the $\mathrm{VL}$. The authors suggested that the reduction of muscle activation may have occurred due to two factors: (1) the carry over effect facilitating knee extension and reduced the need for greater muscle intensity, or (2) joint compression promoted by EKW that may have resulted in neural inhibition of muscle activation. Farther, Gomes et al., ${ }^{8}$ compared the effect of performing vertical jumps with countermovement (SCM) after performing the half-squat exercise with EKW (3 repetitions at 90\% of 1RM). The results showed a reduction of $15 \%$ in the muscular activation of the VL during SCM after the accomplishment of the half-squat with EKW. The authors proposed that the use of the knee elastic band during mid-squatting promoted the carry over effect, reducing VL muscle activity during SCM.

Although there were studies that evaluated the effect of EKW on the kinematic, kinetic and electromyographic variables of the squat exercise (multi-articular), no study was found in the scientific literature to compare the effects of EKW on isolated exercises, that is, where there is no influence of joints acting synergistically, in addition to other muscle groups that may promote changes in both muscle activation and the strength of knee extensors. Thus, the objective of the present study was to compare the effects of elastic knee wrap use on the vastus lateralis muscle activity and knee extensor strength during maximal isometric voluntary contraction (MVIC) in the knee extensor chair.

\section{MATERIALS AND METHODS}

The number of subjects ( $n=18$ ) was determined using a previously conducted pilot study with subjects $(n=5)$ who had the same characteristics as those employed in the present study, based on a significance of $5 \%$ and a power of the test of $80 \% .{ }^{9} \mathrm{~A}$ total of 18 healthy male subjects (age: $25.56 \pm 4.84$ years, total body mass: 81.83 $\pm 8.73 \mathrm{~kg}$, height: $176 \pm 5.17 \mathrm{~cm}$ ), trained in strength (time of practice: $69.33 \pm 60.59$ months) on a regular and uninterrupted, including knee extension for at least one year. All subjects were informed of the experimental procedures and they read and signed the Informed Consent Term approved by the Research Ethics Committee of the University (protocol n 65/2015).

Initially, the dominant lower limb was determined through oral questioning about kick a ball preference, ${ }^{10}$ followed by morphological and anthropometric assessment (total body mass, height, mid-thigh circumference, and total limb length). The subjects presented themselves in the laboratory only once and abstained from any physical activity for at least 48 hours. A brief warm-up on the ergonometric bicycle (Righetto, model R-510V, Brazil) was carried out for five minutes, with a load between 75 and 100 watts at 70 
revolutions per minute. The subjects were then invited to sit on the knee extension chair (Righetto Fitness Equipment, Model PRO-R, Brazil), and this was adjusted so that the knees were at $90^{\circ}$ flexion and aligned with the machine's axis of rotation. Later, trunk and hip were fixed in the seat (by belts) aiming to restrict any movement of the lower limb or trunk during all the experimental conditions. After fixation, subjects were instructed to cross their arms in front of the trunk to perform the specific familiarization with the task consisting of five submaximal isometric contractions (at 50\% of their maximum imaginable contraction $)^{11}$ or three seconds followed by a three minute interval. All force measurements were collected by a load cell (EMG System do Brasil, Brazil) positioned perpendicular to the traction arm of the extensor chair.

The three experimental conditions were performed only in the dominant lower limb, randomized and aimed at measuring muscle strength and activity: control task (C), where the subjects did not use any equipment in the knee; elastic knees wrap (EKW), where the subjects used the elastic band; and tensor ( $T$ ), where the subjects used a tensor without resistance or compression. Initially, in order to quantify only the carry over, the subjects remained seated in the extensor chair at rest, with the anterior region of the ankle joint supported on the roller of the machine (only the dominant member), for the measurement of the passive mechanical tension. Then, three MIVC's of knee extensors were performed, with duration of five seconds for 10 seconds of interval between trials, followed by 10 minutes of rest between experimental conditions. The technique of placement of the EKW employed was in spiral ${ }^{12}$ as tightly as possible, and always performed by the same evaluator. The technique of placement of the EKW employed was in spiral12, as tightly as possible and always performed by the same evaluator. An elastic band of $0.002 \times 0.08 \times 2.00$ m, composed of polyester fabric with interlaced elastodiene filaments (Maba Murphy Confecções Ltda., Brazil, Hard model) was used, with the following mechanical characteristics: modulus of elasticity ( Young's modulus) $(0.47 \pm 0.03 \mathrm{MPa})$, elongation failure $(373.7 \pm 18 \mathrm{~mm})$ and maximum tensile stress $(177.2 \pm 14 \mathrm{MPa}) .{ }^{13}$ It was use a neoprene tensioner with Velcro closure and patellar orifice (TENSOR, Brasil).

Surface Electromyography (SEMG): the vastus lateralis muscular activity data of the dominant limb during knee extension were captured by means of a six-channel surface electromyography (sEMG) (EMG System Brazil, model SAS1000V6, São Jose dos Campos, Brazil). Pairs of active surface electrodes, self-adhesive, Ag/AgCl with $1 \mathrm{~cm}$ of diameter, spaced $2 \mathrm{~cm}$ from center to center between the electrodes, associated with a conductive gel were placed on the vastus lateralis muscle. The location of the electrodes was guided according to SENIAM/ISEKI, ${ }^{14}$ specifically to $2 / 3$ in the line from the superior anterior iliac spine of the lateral portion of the patella. The reference electrode was placed on the patella of the non-dominant side of each subject. For the placement of the electrodes the hairs were removed from the region, followed by a slight abrasion and reduction of the electrical impedance. ${ }^{15-17}$ The sampling frequency adopted was $2000 \mathrm{~Hz}$.

Isometric Force: The isometric force (MVIC e carry over) was measured through a tensile / compression load cell (maximum load of 200 kgf, EMG System do Brasil, São José dos Campos, Brazil), which was fixed perpendicular to the machine movement arm at a 90 degree angle. The acquired data were amplified in 600x, to a frequency of acquisition of $2000 \mathrm{~Hz}$ and synchronized to sEMG through acquisition software (EMG System Brazil, São Jose dos Campos, Brazil).

\section{Data analysis}

All force and sEMG data were processed through a routine written in the software Matlab (Mathworks Inc., USA). The force data were filtered by a fourth-order, low-pass Butterworth $10 \mathrm{~Hz}$ filter. It was defined as standard for further comparison the highest value of the three peak force attempts (MVIC) and the impulse produced in the first two seconds. It should be noted that the peak force and impulse values for all experimental conditions were defined from the subtraction of the carryover value and the MVIC value (real strength value = muscle contraction - carry over).

The sEMG data were analyzed only in the first two seconds after the beginning of the contraction determined by the force curve. The sEMG signal processing proceeded in the following order: filtering using a 4th order Butterworth filter, bandpass between $20-400 \mathrm{~Hz}$, and zero lag. Next, the sEMG data were processed by a root mean square (RMS) windowed at $200 \mathrm{~ms}$, and then the RMS windowed were integrated (IEMG).

\section{Statistical analysis}

The normality and homogeneity of the variances were verified through the Shapiro-Wilk and Levene tests, respectively. A repeated measures ANOVA was used to compare the dependent variables (carry over, force peak, IEMG and Impulse) between the experimental conditions (control, elastic knee wrap and tensor). Then, a Bonferroni Post-hoc test was used to compare the mean of the dependent variables between the conditions. The reliability of the dependent variables were determined using the intra-class correlation coefficient (ICC) following the following criteria: $<0.4$ poor; 0.4 - 0.75 satisfactory; $\geq 0.75$ excellent. ${ }^{18}$ The calculation of the effect size (d) was make using the Cohen formula and the results were based on the parameters suggested by Rhea ${ }^{19}$ for recreationally trained subjects: $<0.35$ trivial effect; 0.35-0.80 small effect; 0.80-1.50 moderate effect; and $>1.50$ great effect. Significance of $5 \%$ was used for all statistical tests, using SPSS software version 21.0.

\section{RESULTS}

For the carry overvariable it was observed that the use of EKW presented a $74.21 \%$ higher value when compared to the control condition $(P<0.001$, $d=0.96)$, and $79.37 \%$ higher when compared to the use of the tensor $(P<0.001, d=0.97)$ (Figure 1A). For the peak of force, an increase of $12.2 \%$ in the control condition was observed when compared to the band $(P=0.018, d=0.71)$ (Figure 1B). The same was observed for the impulse, where the control condition showed an increase of $8 \%$ in relation to the use of EKW ( $P=0.015, d=0.62$ ) (Figure 1C). For the IEMG variable, no significant differences were observed between the analyzed conditions (Figure 1D).

\section{DISCUSSION}

The aim of the present study was to compare the effects of the use of the elastic knee wrap on the vastus lateralis muscle activity and the strength of knee extensors during the maximal isometric voluntary contraction (MVIC) in the extensor chair. The results show that the elastic wrap presented a carry over effect $\sim 74.21 \%$ higher than the control condition and $79.37 \%$ higher than the tensor. These findings corroborate the results obtained by Harman e Frykman ${ }^{3}$ and Gomes et al., ${ }^{6}$ who verified a carry over effect of $\sim 25 \%$ during passive squatting (under suspension) and $22 \%$ during maximum isometric squat, respectively. However, the carry over effect found in the present study was considerably higher than that 


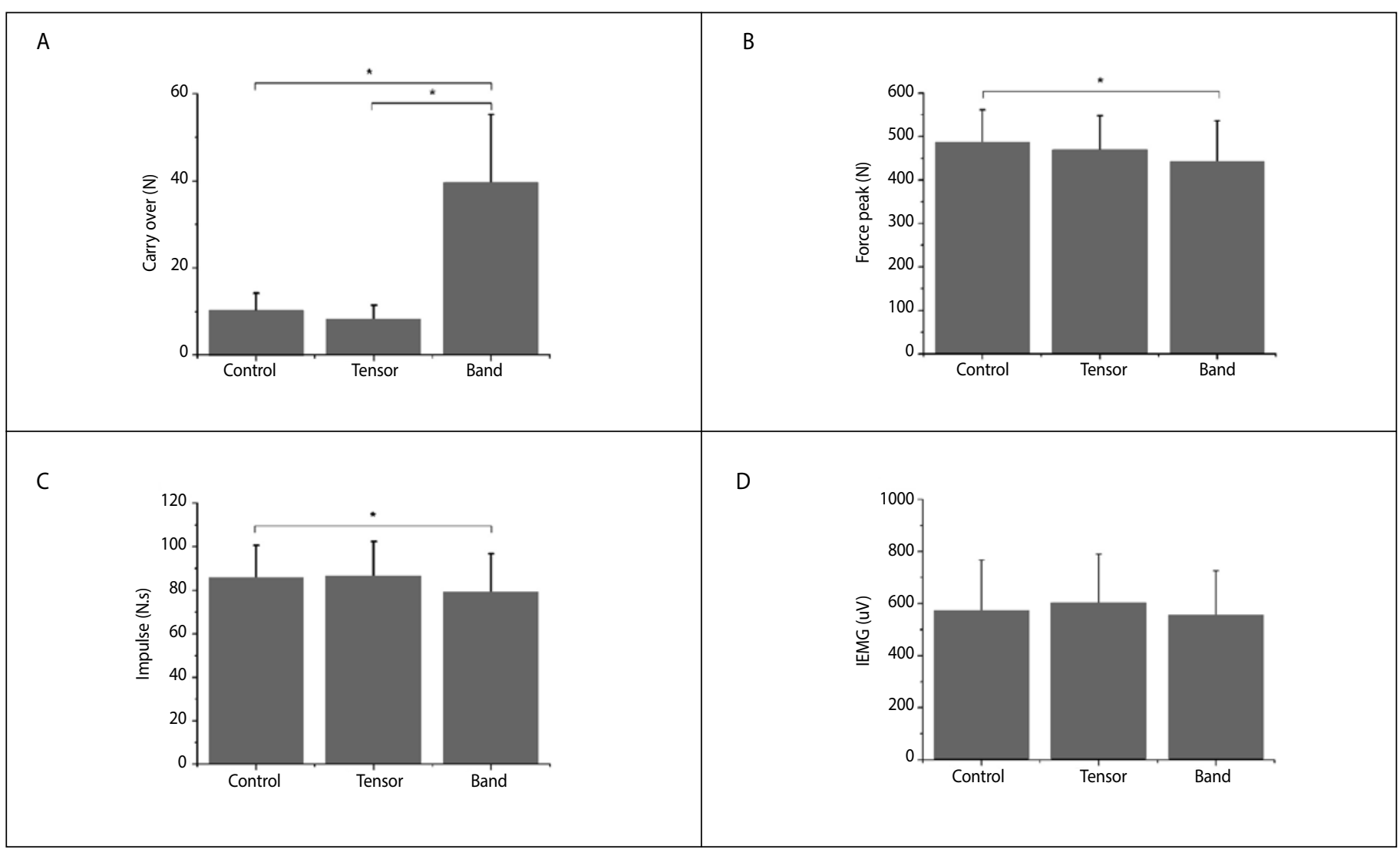

Figure 1. Mean and standard deviation of the dependent variables (A) carry over; (B) force peak; (C) impulse; (D) IEMG for all conditions analyzed. *Significant difference between experimental conditions, $\mathrm{P}<0,05$.

observed in the aforementioned studies. ${ }^{3,6}$ It is probable that EKW contributed with a greater mechanical magnitude during extension of knees in the extensor chair due to the lower external resistance involved during the task (leg and foot segments), which are equivalent to approximately 9.6 and $3.4 \%$ of body weight, respectively. ${ }^{20}$ While performing the maximal isometric squatting exercise, the external resistance is composed of approximately $87 \%$ of body weight ${ }^{20}$ (trunk, upper limbs, neck and head). Thus, it is understood that the carry over effect produced by the wrap can be affected by the type of exercise performed, since the band used in this experiment was of the same make and model used by Gomes et al., ${ }^{6}$ Between the control and tensor conditions, no significant differences were observed between the control and tensor conditions, concluding that the mechanical characteristics of the orthosis did not contribute to the carry over effect as also verified by Marchetti et al., ${ }^{12}$ On the other hand, both the peak force and the impulse were higher for the control condition than for the band condition (12.2\% and $8 \%$, respectively), not corroborating with the findings of Gomes et al., ${ }^{6}$ who verified an increase in peak force of 22 and $21 \%$ (carry over) during the maximum isometric squat with wrap. However, the present study evaluated the effect of EKW during knee extension exercise by removing the effect of additional force produced by the band (carry over effect). In this way, it is assumed that the reduction of the performance of knee extensors with EKW verified in the present study, was due to the joint pressure promoted by the accessory. According Rice e McNair ${ }^{21}$ the knee joint is innervated by afferent fibers (Group II) that are activated by mechanical stimuli (tension and pressure), which may promote inhibition of the alpha motoneurons via type lb sensory neurons, which may have compromised the production capacity of the strength of knee extensors. Curiously, for the IEMG of the vastus lateralis muscle (VL) no significant difference was observed between the analyzed conditions, which did not corroborate with the findings of Gomes et al., ${ }^{7}$ who found a reduction in $\mathrm{VL}$ muscle activation during dynamic squatting with EKW at $90 \%$ of 1 RM. However, the increase in recruitment of motor units is relatively proportional to the increase in activity intensity performed realized. ${ }^{7}$ So, it is likely that the intensity used in our (maximum) study has provided a similar recruitment of motor units between the experimental conditions. In addition, our study evaluated the effect of EKW during maximal isometric contractions, which generally present a relatively stable sEMG signal when compared to dynamic activities. ${ }^{15}$ Besides, the present study compared the effects of EKW on an isolated exercise, nullifying the influence of other muscle groups and joints. Therefore, the results of the present study cannot be extrapolated to dynamic and multi-articular exercises, since the type of exercise and the way of doing it can alter the results obtained.

\section{CONCLUSION}

It was concluded that the use of elastic knee wrap promoted an increase in the capacity of force production during knee extension (carry over effect). However, removal of the mechanical effect from the carry over during maximal isometric contraction reduces the strength performance of knee extensors, but not the muscular activation of the vastus lateralis.

All authors declare no potential conflict of interest related to this article.

AUTHORS' CONTRIBUTIONS: Each author made significant individual contributions to this manuscript. FSF (0000-0003-4872-0077)* and WAG (0000-0003-4223-8917)* contributed to the design of the experiment, the data collection, and the writing of the manuscript. PHM (0000-0002-2016-936X)* contributed to the data analysis and the critical review of the intellectual content. *ORCID (Open Researcher and Contributor ID). 


\section{REFERENCES}

1. Totten L. Knee wraps. J Strength Cond Res. 1990;12:36-8.

2. Gomes WA, Coutinho M, Marchetti PH. Revisão dos efeitos biomecânicos do uso de banda elástica no joelho durante o agachamento no levantamento básico. Revista CPAQV. 2013;5(3):1-15.

3. Harman E, Frykman P. The effects of knee wraps on weightlifting performance and injury. Nat Strength Cond J. 1990;12(5):30-5.

4. Lake J, Carden P, Shorter K. Knee wraps affect squat performance. J Strength Cond Res. 2012;8(1):1-16.

5. Coutinho M. De volta ao básico: powerlifting - treinamento funcional, esporte de alto rendimento e prática coporal para todos. São Paulo: Editora Phorte; 2011.

6. Gomes WA, Serpa EP, Soares EG, da Silva JJ, Corrêa DA, de Oliveira FHD, et al. Acute effects on maximal isometric force with and without knee wrap during squat exercise. Int J Sports Sci. 2014;4(2):47-9.

7. Gomes WA, Brown LE, Soares EG, Silva JJ, Silva FHDO, Serpa EP, et al. Kinematic and sEMG analysis of the back squat at different intensities with and without knee wraps. J Strength Cond Res. 2015;29(9):2482-7.

8. Gomes WA, Silva JJ, Soares EG, Serpa EP, Corrêa DA, Vilela Junior GB, et al. Efeitos agudos no desempenho do salto vertical após o agachamento com banda elástica de joelho. Rev Bras Med Esporte. 2015;21(4):257-60.

9. Eng J. Sample Size Estimation: How many individuals should be studied? Radiology. 2003;227(2):309-13.

10. Maulder P, Cronin J. Horizontal and vertical jump assessment: reliability, symmetry, discriminative and predictive ability. Phys Ther Sport. 2005;6(2):74-82.

11. Behm DG, Cavanaugh T, Quigley P, Reid JC, Nardi PSM, Marchetti PH. Acute bouts of upper and lower body static and dynamic stretching increase non-local joint range of motion. Eur J Appl Physiol. 2016;116(1):241-9.
12. Marchetti PH, Matos VJP, Soares EG, Silva JJ, Serpa EP, Corrêa DA, et al. Can the technique of knee wrap placement affect the maximal isometric force during back squat exercise? Int J Sports Sci. 2015;5(1):16-8.

13. Gomes WA, Ferreira AM, Marchetti PH. Comparação entre diferentes tipos de bandas elásticas de joelho: uma análise de suas características mecânicas e efeitos no treinamento de força. In: Zanesco A, editor. IX Congresso Internacional de Educação Física e Motricidade Humana XV Simpósio Paulista de Educação Física (VIII CIEFMH e XIV SPEF). Rio Claro, São Paulo: Motriz; 2015. p. 70-1.

14. Hermens HJ, Freriks B, Disselhorst-Klug C, Rau G. Development of recommendations for SEMG sensors and sensor placement procedures. J Electromyogr Kinesiol. 2000;10(5):361-74.

15. De Luca CJ. The use of surface electromyography in biomechanics. J Appl Biomech. 2003;13(2):135-63.

16. De Luca CJ. Electromyography. Encyclopedia of Medical Devices and Instrumentation. Boston: John Wiley Publisher; 2006. p. 98-109.

17. Marchetti PH, Duarte M. Eletromiografia: uma breve revisão sobre os procedimentos de aquisição do sinal. Terapia Manual. 2011;9(44):548-53

18. Rosner B. Fundamentals of Biostatistics. Boston: Cengage Learning; 2010

19. Rhea MR. Determining the magnitude of treatment effects in strength training research through the use of the effect size. J Strength Cond Res. 2004;18(4):918-20

20. Marchetti PH, Calheiros Neto RB, Charro MA. Biomecânica Aplicada: Uma abordagem para o treinamento de força. São Paulo: Phorte; 2007.

21. Rice DA, McNair PJ. Quadriceps arthrogenic muscle inhibition: neural mechanisms and treatment perspectives. Semin Arthritis Rheum. 2010;40(3):250-66. 